\title{
UWAGI METODOLOGICZNE NA TEMAT BADAŃ NAD POCHODZENIEM CZŁOWIEKA ${ }^{1}$
}

\begin{abstract}
Streszczenie. Pytanie o początki człowieka, stawiane na gruncie nauk biologicznych, jest pytaniem o linię filogenetyczną, wiodącą do pojawienia się gatunku Homo sapiens. Dysponując jakąś hipotezą, dotyczącą przebiegu tej linii, biolog może starać się ustalić, kiedy i gdzie zaszła zmiana na tyle decydująca, że należy ją uznać za równoznaczną powstaniu naszego - prawdziwie nowego - gatunku. Problem polega jednak na tym, że kryteria, pozwalające jednoznacznie odróżnić jeden gatunek od drugiego, wydają się być trudne, a być może nawet niemożliwe do sformułowania. Oznacza to, że samo pojęcie „prawdziwie nowego" gatunku jest w pewnym sensie puste. W artykule zostały ukazane kluczowe problemy metodologiczne, występujące na gruncie antropologii przyrodniczej, mające znaczenie dla jej ustaleń.
\end{abstract}

Słowa kluczowe: gatunek; ewolucja; Homo sapiens; antropologia przyrodnicza; metody badawcze

1. Wstęp. 2. Ciągły charakter procesów ewolucyjnych. 3. Pojęcie gatunku w paleontologii. 4. Genetyczne granice między gatunkami? 5. Antropologia przyrodnicza i jej metody. 6. Zakończenie.

\section{WSTĘP}

Z wiary w stworzenie człowieka przez Boga zdaje się wynikać przekonanie o tym, że człowiek jest istotą wyjątkową - zasadniczo różną od wszelkich innych stworzeń. To właśnie było jednym z powodów, dla których dzieło Karola Darwina przyjęte zostało z niepokojem przez niektórych współczesnych mu chrześcijan, a i dziś budzi czasem podobny niepokój, ponieważ człowiek został w nim potraktowany

1 Niniejszy artykuł jest dotąd niepublikowanym tekstem autorstwa Grzegorz Bugajaka, odnalezionym w jego archiwum po jego śmierci. Redakcja dokonała modyfikacji tytułu oraz podziału struktury tekstu, a także częściowo uzupełniła przypisy. 
jak każdy inny gatunek biologiczny. Nowe gatunki zaś pojawiają się w świecie przyrody dzięki powolnej, stopniowej ewolucji z innych gatunków i choć są od swoich poprzedników różne (dzięki tym różnicom właśnie możemy zaliczać poszczególne osobniki do odmiennych gatunków), to jednak nie są jakoś szczególnie wyjątkowe - podobnie, jak dzieci różnią się od swoich rodziców, lecz są do nich zasadniczo podobne ${ }^{2}$. Stajemy zatem wobec pytania, czy człowiek jest, czy nie jest w jakimś sensie istotą wyjątkową, skoro jest „dzieckiem” ewolucji. Pytanie to, postawione na gruncie nauk biologicznych, sprowadza się do kwestii odrębności (filozof powiedziałby: istotnej odrębności) gatunku Homo sapiens od reszty świata przyrody³.

\section{CIĄGŁY CHARAKTER PROCESÓW EWOLUCYJNYCH}

Darwinowska teoria ewolucji, a także inne post-darwinowskie próby opisania procesu ewolucji, mają na celu wyjaśnienie naturalnych przyczyn i mechanizmów zmian w świecie organicznym, które zachodzą $\mathrm{w}$ stosunkowo długich okresach czasu i dotyczą wielu pokoleń. Ewolucja rozumiana w ten sposób ma niewielkie znaczenie dla kontrowersji między ewolucjonizmem i przekonaniami dotyczącymi stworzenia świata i człowieka; wywoływać może jedynie dyskusje, dotyczące wspomnianych mechanizmów (jak np. selekcja naturalna), na które wskazywał sam Darwin i jego następcy. Specjaliści mogą w szczególności poszukiwać innych czynników wiodących do owych zmian

2 Kwestia tempa procesów ewolucyjnych i charakteru zmian, jakie one przynoszą (czy są to zmiany drobne, niewielkie, czy skokowe), jest przedmiotem dyskusji specjalistów. W szczególności, nie wszystkie post-darwinowskie teorie ewolucji mówią, że zmiany te koniecznie muszą być stopniowe i powolne (kontrowersja między gradualizmem a punktualizmem). Tutaj jednak odnosimy się do oryginalnych idei Darwina. Co więcej, nawet jeśli poszczególne gatunki (lub choćby tylko niektóre z nich), w tym gatunek ludzki, pojawiają się wskutek zmian gwałtownych i przynoszących „od razu” poważne zmiany anatomiczne czy fizjologiczne, to jednak pozostaje pytanie, czy w ten sposób może powstać gatunek istotnie odrębny od swoich przodków.

3 Por. J. Tomczyk, Antropologia filozoficzna i przyrodnicza w poszukiwaniu istoty człowieka, Studia Philosophiae Christianae 39(2003)1, 120-135. 
$\mathrm{w}$ świecie istot żywych i dyskutować, które z nich mają w owym procesie znaczenie decydujące. Ta niewątpliwie ważna kwestia jest przedmiotem rozważań biologów ewolucyjnych i nie widać powodu, dla którego winna niepokoić teologów czy ludzi wierzących. Inaczej jednak rzecz się ma z próbami opisu i wyjaśnienia przebiegu ewolucji, tj. filogenezy (genezy poszczególnych gatunków). Filogenetyczne hipotezy, mówiące o tym, jaki gatunek jest przodkiem jakiego (tzw. hipotezy przodek-potomek), zmierzają do zrekonstruowania linii następujących po sobie generacji i do wskazania - na przykład - jak współczesne gatunki są spokrewnione ze sobą i ze swoimi wspólnymi przodkami. Jak widać, $\mathrm{w}$ rekonstrukcjach takich istotną rolę pełni pojęcie gatunku. Wraz z następującymi po sobie pokoleniami przodków i ich potomków z danych gatunków powstają nowe, zaś gatunki poprzednie rozwijają się odtąd niezależnie, a nierzadko wymierają. Ten generalny schemat ma zastosowanie do wszystkich obecnie żyjących i dawnych gatunków, i nawet gdy nie jest możliwe prześledzenie danej linii filogenetycznej (choćby z powodu niedostatecznego zapisu kopalnego - braku lub słabej jakości odnalezionych skamieniałości), przyjmuje się, że taka linia istniała. Ma to naturalnie zastosowanie także w odniesieniu do gatunku Homo sapiens. Pytanie o początki człowieka, postawione na gruncie nauk biologicznych, jest zatem pytaniem o linię filogenetyczną wiodącą do tego gatunku. Dysponując jakąś hipotezą, dotyczącą przebiegu tej linii (przynajmniej w odniesieniu do bezpośrednich przodków Homo sapiens, a więc sugestią na temat tego, z populacji jakiego gatunku wyewoluował nasz), biolog może następnie pytać, kiedy i gdzie zaszła zmiana na tyle decydująca, że można ją uznać za równoznaczną powstaniu naszego - prawdziwie nowego - gatunku ${ }^{4}$. Problem polega jednak na tym, że kryteria, pozwalające jednoznacznie odróżnić jeden gatunek

4 J. Tomczyk, Początki Homo sapiens a problem definicyjności gatunku, w: Kontrowersje wokół początków człowieka, red. G. Bugajak, J. Tomczyk, Księgarnia św. Jacka, Katowice 2007, 98-111. 
od drugiego, wydają się być trudne, a być może nawet niemożliwe do sformułowania. Oznacza to, że samo pojęcie „prawdziwie nowego” gatunku jest w pewnym sensie puste.

Konwencjonalny charakter pojęcia gatunku może być wykazany $z$ różnych punktów widzenia. Niżej rozważymy jego funkcjonowanie w paleontologii, genetyce i antropologii - dziedzinach, w których jego umowny charakter wydaje się szczególnie oczywisty.

\section{POJĘCIE GATUNKU W PALEONTOLOGII}

W wielu naukach biologicznych pojęcie gatunku można definiować w sposób obiektywny (jak choćby „klasyczna” definicja, odwołująca się do możliwości reprodukcyjnych i określająca, że dwa osobniki należą do tego samego gatunku, jeśli mogą mieć płodne potomstwo) ${ }^{5}$. Jednak tego rodzaju definicje nie mają zastosowania w paleontologiiw odniesieniu do populacji kopalnych. Dlatego sensowne używanie pojęcia gatunku w tej dziedzinie wymaga najczęściej zastosowania pewnego rodzaju analizy statystycznej. Analiza taka oparta jest na założeniu (a w zasadzie na swoistym prawie przyrody), że wśród organizmów rozmnażających się płciowo, rozkład najbardziej charakterystycznych cech morfologicznych w populacji jest bliski rozkładowi Gaussa (tzw. rozkład normalny).

Cechy, które poddaje się analizie (np. szczegóły morfologii), zmieniają się stopniowo z czasem i w kolejnych populacjach mogą różnić się nieznacznie. Jeśli jednak rozkład badanej cechy zmienia się w sposób statystycznie znaczący, np. jeśli jest ona charakterystyczna dla większości osobników w populacji A, zaś nie występuje w przypadku większości osobników populacji B, gdzie „większośc”

5 Zob. E. Mayr, Towards a New Philosophy of Biology. Observations of an Evolutionist, The Belknap Press of Harvard University Press, Chicago 1988, 318. Fachowe definicje gatunku nigdy nie dotyczą pojedynczych osobników, lecz populacji. Dlatego, ściślej mówiąc, w myśl definicji biologicznej za gatunki należy uważać grupy krzyżujących się naturalnych populacji, rozrodczo izolowanych od innych takich grup. 
może na przykład oznaczać zawieranie się w ramach jednego odchylenia standardowego (dyspersji) w rozkładzie Gaussa, co oznacza występowanie (lub - odpowiednio - brak) danej cechy u ok. 68\% przedstawicieli populacji, to osobniki należące do populacji A zalicza się do innego gatunku niż te, które należą do populacji B. Taki sposób definiowania gatunku jest niewątpliwie użyteczny, niemniej granica, którą można wykreślić między poszczególnymi gatunkami przy użyciu tej metody, jest w sposób oczywisty konwencjonalna. Jej konwencjonalny charakter wynika stąd, że dyskretną, „punktową” siatkę pojęć nakłada się na ciągły obraz ewolucyjnych zmian.

Znaczenie tego sposobu odróżniania od siebie różnych gatunków, jaki spotykamy w paleontologii, jest dla problematyki początków człowieka istotne $\mathrm{z}$ dwóch powodów. Spoglądając w dół naszego filogenetycznego drzewa poszukujemy na nim takiego "momentu” czy „miejsca” w historii życia na naszej planecie, w którym pojawiła się pierwsza populacja ludzka. Czyniąc to, nie mamy innego wyboru, jak tylko użyć metod paleontologicznych - wszak badamy właśnie historię form przedludzkich. A wraz z nimi przyjmujemy takie pojęcie gatunku, jakie jest właściwe i możliwe do zastosowania w ramach owych metod. Wynika stąd, że to, co możemy znaleźć przy użyciu owych metod, to nie jakiś rodzaj „prawdziwego” początku ludzkości, lecz początek gatunku, który uprzednio zdecydowaliśmy się zdefiniować w taki, a nie inny sposób. Co więcej (i to ów drugi powód), taki konwencjonalny charakter pojęcia gatunku nie jest jedynie naszym wyborem, który czynimy z powodów praktycznych, lecz wynika z ciągłego charakteru procesów ewolucyjnych. Prześledzenie zmian ewolucyjnych w populacjach kopalnych pokazuje, że ciągły charakter tego procesu jest niezależny od środowiska, w którym zachodzi, ani też od stopnia rozwoju organizmów, które mu podlegają - co dotyczy także naczelnych wraz z człowiekiem ${ }^{6}$. Można więc powiedzieć,

6 Zob. J. Dzik, Sposoby odczytywania kopalnego zapisu ewolucji, w: Kontrowersje wokół początków człowieka, dz. cyt., 65-86. 
jakkolwiek paradoksalnie by to brzmiało, że nie tylko nie jesteśmy w stanie uchwycić momentu pojawienia się pierwszego człowieka, ale że momentu takiego - w sensie wyżej wskazanym - nigdy nie było.

\section{GENETYCZNE GRANICE MIĘDZY GATUNKAMI?}

Bezpośrednia rekonstrukcja naszej filogenetycznej przeszłości przy użyciu metod biologii molekularnej nie jest możliwa. Przodkowie człowieka to gatunki wymarłe i obecnie w naszym zasięgu są jedynie ich skamieniałe szczątki, z których można uzyskać niewiele danych dotyczących ich materiału genetycznego. Możliwa jest natomiast analiza genomu gatunków współczesnych. Analiza taka może wskazać na genetyczne podstawy różnic między danymi gatunkami oraz - przy przyjęciu dodatkowych, zwykle niekontrowersyjnych założeń - prowadzić do próby odtworzenia historii zmian ewolucyjnych. Wyposażenie genetyczne człowieka zostało poznane (w fachowej terminologii: genom został zsekwencjonowany), zaś wyniki sekwencjonowania genomu innego gatunku naczelnych - szympansa zostało zakończone w 2005 roku. Porównanie tych dwu genomów wskazało na około 500 genów, w których różnice są największe, a zatem przypuszczalnie decydujące o różnicach w morfologii, wrodzonych wzorcach zachowania się i innych odmiennościach tych dwu gatunków7. Choć nie jesteśmy „potomkami” szympansów (wbrew powtarzanemu często błędnemu stwierdzeniu, pochodzącemu jeszcze z czasów Darwina i jego ówczesnych oponentów, o człowieku pochodzącym od małpy), a tylko mamy z tym gatunkiem wspólnych „przodków”, to porównanie naszych genomów może doprowadzić do rozpoznania drogi zmian ewolucyjnych, które przyniosły powstanie tych dwu różnych gatunków. Można bowiem założyć, że różnice między ludźmi i ich bezpośrednimi przodkami (niezależnie od tego,

7 Zob. P. Stępień, Ciągłość czy moment? Rozważania genetyka, w: Kontrowersje wokół początków człowieka, dz. cyt., 23-26. 
że jak dotąd nie ma pewności, do jakiego konkretnie gatunku ci przodkowie należeli) były podobnego stopnia i rodzaju jak te, które różnią nas na poziomie genetycznym od szympansów.

Załóżmy zatem, że główne genetyczne różnice między Homo sapiens a gatunkiem, z którego ten wyewoluował, wyrażały się w mniej więcej pięciuset genach. Kluczowe w poprzednim zdaniu jest wyrażenie „mniej więcej”. Stajemy bowiem wobec pytania, kiedy kumulujące się stopniowo zmiany doprowadziły do różnicy, decydującej o gatunkowej odrębności gatunku ludzkiego od jego ewolucyjnego przodka. Czy stało się to w momencie, gdy poważnie odmiennych genów pojawiło się 495, czy może 503? Jest jasne, że podanie konkretnej liczby jest tu niemożliwe, i to nie dlatego, że brak nam obecnie zadowalających danych, na mocy których można by ją oszacować, lecz z powodów zasadniczych. Trudno przecież twierdzić, iż gatunkowa różnica między człowiekiem a jego przodkiem mieści się w jakimś jednym, konkretnym genie, ani też, że zależy od przekroczenia dokładnie określonej liczby genów różniących te dwa gatunki. Jest więc jasne, że międzygatunkowa granica, której tu poszukujemy, jest znów konwencjonalna: jej znalezienie nie jest możliwe; możemy jedynie zdecydować, gdzie chcemy ją wykreślić.

\section{ANTROPOLOGIA PRZYRODNICZA I JEJ METODY}

Zwrócenie uwagi na pewne metodologiczne zagadnienia antropologii przyrodniczej i na przykłady dokonywanych w historii tej dziedziny klasyfikacji taksonomicznych dotyczących paleoantropologicznych odkryć, wskazuje, że nawet ta dyscyplina, która bezpośrednio zajmuje się badaniem przeszłości i początków Homo sapiens, nie ma i przypuszczalnie mieć nie może - żadnej „poprawnej”, czy ,jedynej” definicji człowieka. Jeśli ta konstatacja okaże się słuszna, to każda odpowiedź na pytanie o miejsce i czas powstania naszego gatunku może być - podobnie jak w przypadku rozważanych wyżej paleontologii i genetyki - jedynie konwencjonalna, gdyż będzie zależeć od mniej czy bardziej dowolnie wybranej definicji. 
Istnieją trzy podstawowe sposoby badania przeszłości naszego gatunku, które stanowią odpowiednio o trzech metodach stosowanych $\mathrm{w}$ antropologii ${ }^{8}$. Badania takie moga polegać na analizie skamieniałości (metoda morfologiczna), na interpretacji archeologicznych artefaktów (metoda archeologiczna) lub na analizie molekularnej (metoda genetyczna).

Pierwsza $z$ nich (najstarsza $z$ metod używanych $w$ antropologii) - metoda morfologiczna - polega na próbie określenia stopnia pokrewieństwa między organizmami kopalnymi i współczesnymi za pomocą analizy porównawczej materiału kostnego. Kryteria morfologiczne, używane przy klasyfikacji skamieniałości jako pochodzących od osobników danego gatunku, są różnego rodzaju. Przypisując danym skamielinom rolę reprezentantów przodków Homo, bierze się, dla przykładu, pod uwagę morfologię uzębienia, dwunożność (którą wnioskuje się na podstawie struktury pewnych kości), czy wielkość mózgoczaszki. Przy użyciu tej metody pierwsi reprezentanci naszego gatunku zostali zidentyfikowani w szczątkach datowanych jako pochodzące sprzed ok. 400 tys. lat.

Szczątki z Afryki, m.in. z Kabwe, Ndutu czy Bodo, znamionuje wprawdzie wiele cech wspólnych $z$ afrykańskim Homo erectus, jednak na uwagę zasługuje fakt powiększenia pojemności mózgoczaszki do ok. $1200 \mathrm{~cm}^{3}$, czy zwiększenia gracylności (delikatności) szkieletu. Pozostałości te korelują swą morfologią z nieco młodszymi afrykańskimi szczątkami, datowanymi na 200-100 tys. 1at, z Leatoli 18, Jebel Irhoud, Florisbad. Mimo, iż czaszki te są dość szerokie, długie i słabo wysklepione a wały nadoczodołowe są znacznych rozmiarów, to jednak pojemność mózgoczaszki wzrasta do około $1350 \mathrm{~cm}^{3}$, a twarzoczaszka i szkielet postkranialny jest dość gracylny. Natomiast szczątki sprzed 100 tys. lat z Omo-Kibish 1, Border Cave czy Klasies River Mouth swą morfologią całkowicie przypominają współcześnie

8 Zob. B. Hałaczek, J. Tomczyk, U progów ludzkości, t. 1, Wydawnictwo UKSW, Warszawa 2005. 
żyjącego Homo sapiens. W świetle przyjętego kryterium morfologicznego całkowicie usprawiedliwione wydaje się nazwanie owych najstarszych afrykańskich szczątków mianem wczesny archaiczny Homo sapiens, młodszych, bo sprzed 200-100 tys. lat - pózny archaiczny Homo sapiens, tych zaś datowanych na 100 tys. lat - nowoczesny anatomicznie Homo sapiens. Niemniej jednak należy pamiętać, że przyjęte nazwy spełniają jedynie funkcję pomocniczą, ułatwiającą orientację w ludzkiej przeszłości i to tylko przy założeniu, iż wspomniane kryteria morfologiczne są akceptowane9.

Metoda archeologiczna określa przynależność do danego gatunku na podstawie wzorów zachowań jego przedstawicieli, odzwierciedlanych w takich znaleziskach jak narzędzia, miejsca pochówku, czy przedmioty klasyfikowane jako wytwory sztuki lub rzemiosła. Wnioskowanie o zachowaniach, charakterystycznych dla danej populacji, na podstawie takich znalezisk, jak wyżej wspomniane (czy nawet o „poglądach” jej przedstawicieli, jak na przykład twierdzenie, że ślady wskazujące na rytualny charakter pochówku świadczą o jakiejśs świadomości transcendencji), wymaga przyjęcia silnych hipotez pomocniczych. Archeologiczne szczątki nie są przecież „filmem”, który przedstawiałby życie jej przedstawicieli. Zatem wartość takich wniosków zależy od zasadności owych dodatkowych hipotez. Problem ten jednakże jest wewnętrznym zagadnieniem antropologii i omawianej tutaj jednej z jej metod, dlatego uzasadnienie jej wiarygodności jest sprawą specjalistów, posługujących się tą metodą w rozważaniach antropologicznych. $Z$ naszego punktu widzenia ważne jest natomiast, że wyniki badań, przeprowadzanych przy jej użyciu, prowadzą do wniosku, że historia ludzkości miała swój początek zaledwie 30-45 tys. lat temu. $\mathrm{Z}$ takiego bowiem okresu pochodzą takie znaleziska jak malowidła naskalne czy dość zaawansowane narzędzia. Wykonywanie zaś podobnych malowideł i wytwarzanie wspomnianych

9 Zob. J. Tomczyk, The Origin of Homo sapiens in the Light of Different Research Methods, Human Evolution 21(2006), 203-213. 
narzędzi uważane jest w ramach omawianej metody za „dowód” tego, iż ich twórcy byli ludźmi.

Ostatnia ze wspomnianych metod - genetyczna - zmierza do odpowiedzi na pytanie, jakie zmiany w sekwencji nukleotydów iw konsekwencji - pojawienie się jakich właściwości funkcjonalnych białek doprowadziło do pojawienia się człowieka. Określając przy tym tempo zachodzenia zmian genetycznych, próbuje też wskazać na czas, w jakim pojawiały się na poziomie molekularnym poszczególne funkcjonalne nowości ${ }^{10}$. Analizy podjęte przy użyciu tej metody przesuwają początki naszych dalekich przodków (oddzielenie się ludzkiej gałęzi ewolucyjnej od drzewa naczelnych) aż na okres sprzed 6-7 mln. lat lub nawet wcześniej, zaś molekularną tożsamość Człowieka Współczesnego znajdują ok. 200 tys. lat temu.

Jak widzimy, wskazanie na początek gatunku ludzkiego jest silnie uzależnione od metody badań. Różne oszacowania czasu powstania Homo sapiens są wzajemnie niezgodne. Kontrowersje, jakie pojawiają się w antropologii, spowodowane przez sam fakt używania w tej dziedzinie różnych metod, dobrze ilustruje historia taksonomicznej klasyfikacji Neandertalczyka. Podejście w ramach metody antropologicznej wydawało się wskazywać, że choć Neandertalczyk należał do rodzaju Homo (o czym świadczyła duża mózgoczaszka), to jednak nie był przedstawicielem Homo sapiens (gdyż jego szkielet był zbyt masywny). Opinia ta jednak została podana w wątpliwość, gdy odkrycia archeologiczne wskazały, że Neandertalczycy grzebali swoich zmarłych, a nawet stosowali przypuszczalnie rytuały pogrzebowe. Tym samym metoda archeologiczna zmusiła do zaklasyfikowania Neandertalczyka jako wymarłej gałęzi ewolucyjnej człowieka współczesnego. Odkrycia te znalazły swoje odzwierciedlenie w klasyfikacji taksonomicznej: Neandertalczyk przestał być traktowany jako

10 Zob. S. Pääbo, H. Poinar, D. Serre, V. Jaenicke-Després, J. Hebler, N. Rohland, M. Kuch, J. Krause, L. Vigilant, M. Hofreiter, Genetic Analyses from Ancient DNA, Annual Review of Genetics 38(2004), 645-679. 
gatunek inny niż Homo sapiens (i nazywany Homo neandertalensis), lecz został zaklasyfikowany jako podgatunek gatunku ludzkiego (Homo sapiens neandertalensis).

Zależność definicji „prawdziwego” człowieka od założeń danej metody badania ludzkiej przeszłości jest widoczna nie tylko przy porównaniu wyników uzyskanych przy użyciu różnych metod, lecz także niejako „wewnątrz” każdej z nich. Przykładem tego może być krótka kariera Oreopiteka jako rzekomego przodka ludzi współczesnych. Analiza metodą morfologiczną wskazywała na jego przynależność do rodziny Hominidae ze względu na charakterystykę uzębienia. Ta klasyfikacja została jednak odrzucona, gdy w ramach metody morfologicznej zaczęto zwracać uwagę na możliwość utrzymywania postawy wyprostowanej, jako charakterystyczną dla przedstawicieli Hominidae. Oreopitecus zaś tej cechy nie miał ${ }^{11}$.

\section{ZAKOŃCZENIE}

Różnorodność metod badawczych w antropologii nie jest rzeczą ani dziwną, ani naganną. Nie ma też nic zaskakującego w tym, że „definicja człowieka” zależy od metody, za pomocą której bada się ludzką przeszłość - to metoda właśnie wyznacza zbiór cech, które uważa się za typowo ludzkie. Co warto jednak podkreślić, nawet jeśli zwolennicy poszczególnych metod antropologicznych mogliby osiągnąc jakiś rodzaj porozumienia i w konsekwencji sformułować zgodną „definicję człowieka”, to definicja taka byłaby z konieczności

11 W 1872 roku okryto w prowincji Grosseto w Toskanii pierwsze szczątki oreopiteka (Oreopithecus bambolii). W opinii wielu paleoantropologów osobnik ten był uważany za najstarszego, bo liczącego $10 \mathrm{mln}$ lat, reprezentanta hominidów. Teza ta jednak oparta była na mocno fragmentarycznym materiale. Kolejne wykopaliska z terenów północnych Włoch dostarczyły nowych informacji o oreopiteku. Spowodowało to, że już w latach 70. zaczęto podważać hominidalny status oreopitka. Dziś uważany jest on jedynie za kopalną małpę człekokształtną. Zob. M. Köhler, S. Moyà-Solà, Ape-like or hominid-like? The positional behavior of Oreopithecus bambolii reconsidered, Proceedings of the National Academy of Sciences 94(1997), 11747-11750. 
umowna. Wybór kryteriów (obojętnie, czy byłyby to kryteria morfologiczne, archeologiczne, genetyczne, czy jakiekolwiek inne), zgodnie z którymi formy kopalne mogą być klasyfikowane jako ludzcy przedstawiciele naszych przodków, będzie zawsze arbitralny. Nie świadczy to naturalnie o słabości metod badawczych, lecz jest konsekwencją faktu, że dokonując takiej czy innej klasyfikacji antropologicznych znalezisk, próbujemy narzucić dyskretną siatkę pojęć na zjawiska ewolucyjne, które mają charakter ciągły. Gatunek nasz wyłonił się zaś w wyniku takich właśnie zjawisk o ciągłym charakterze. Linia filogenetyczna wiodąca do człowieka, niezależnie od tego, że szczegółów jej przebiegu nie znamy, przebiega łagodnie - nie istnieją obiektywne granice, czy „punkty nieciągłości”, na które moglibyśmy wskazać jako na „czas i miejsce” powstania człowieka.

\section{BIBLIOGRAFIA}

Dzik J., Sposoby odczytywania kopalnego zapisu ewolucji, w: Kontrowersje wokót początków człowieka, red. G. Bugajak, J. Tomczyk, Księgarnia św. Jacka, Katowice 2007, 65-86.

Hałaczek B., Tomczyk J., U progów ludzkości, t. 1, Wydawnictwo UKSW, Warszawa 2005.

Köhler M., Moyà-Solà S., Ape-like or hominid-like? The positional behavior of Oreopithecus bambolii reconsidered, Proceedings of the National Academy of Sciences 94(1997), 11747-11750.

Mayr E., Towards a New Philosophy of Biology. Observations of an Evolutionist, The Belknap Press of Harvard University Press, Chicago 1988.

Pääbo S., Poinar H., Serre D., Jaenicke-Després V., Hebler J., Rohland N., Kuch M., Krause J., Vigilant L., Hofreiter M., Genetic Analyses from Ancient DNA, Annual Review of Genetics 38(2004), 645-679.

Stępień P., Ciagtość czy moment? Rozważania genetyka, w: Kontrowersje wokót początków cztorwieka, red. G. Bugajak, J. Tomczyk, Księgarnia św. Jacka, Katowice 2007, 23-26.

Tomczyk J., Antropologia filozoficzna i przyrodnicza w poszukiwaniu istoty cztowieka, Studia Philosophiae Christianae 39(2003)1, 120-135. 
Tomczyk J., Poczatki Homo sapiens a problem definicyjności gatunku, w: Kontrowersje wokót początków cztowieka, red. G. Bugajak, J. Tomczyk, Księgarnia św. Jacka, Katowice 2007, 98-111.

Tomczyk J., The Origin of Homo sapiens in the Light of Different Research Methods, Human Evolution 21(2006), 203-213.

\title{
METHODOLOGICAL REMARKS ON ANTHROPOLOGICAL RESEARCH ON THE ORIGIN OF MAN
}

\begin{abstract}
The question about the origins of man posed in the field of biological sciences, concerns the phylogenetic line leading to the appearance of the species Homo sapiens. According to a certain hypothesis about the course of this lineage, a biologist may try to determine when and where a change took place, so decisive that it should be considered the creation of our - really new - species. The problem, however, is that the criteria for clearly distinguishing one species from another appear to be difficult, if not impossible, to formulate. This means that the very concept of a "really new" species is somewhat empty. This article illustrates the key methodological problems in the field of natural anthropology that are relevant for its findings.
\end{abstract}

Keywords: specie; evolution; Homo sapiens; anthropology; research methods

Grzegorz Bugajak

Uniwersytet Kardynała Stefana Wyszyńskiego w Warszawie, Instytut Filozofii

(Cardinal Stefan Wyszyński University in Warsaw, Institute of Philosophy, Poland)

ORCID: https://orcid.org/0000-0003-0536-1254

DOI: $10.21697 /$ spch.2020.56.4.01 